\title{
WORLD WIDE WEB ACCESS TO PUBLICATIONS AND DATA FOR THE APALACHICOLA-CHATTAHOOCHEE-FLINT RIVER BASIN-GEORGIA, FLORIDA, AND ALABAMA, 1992-95
}

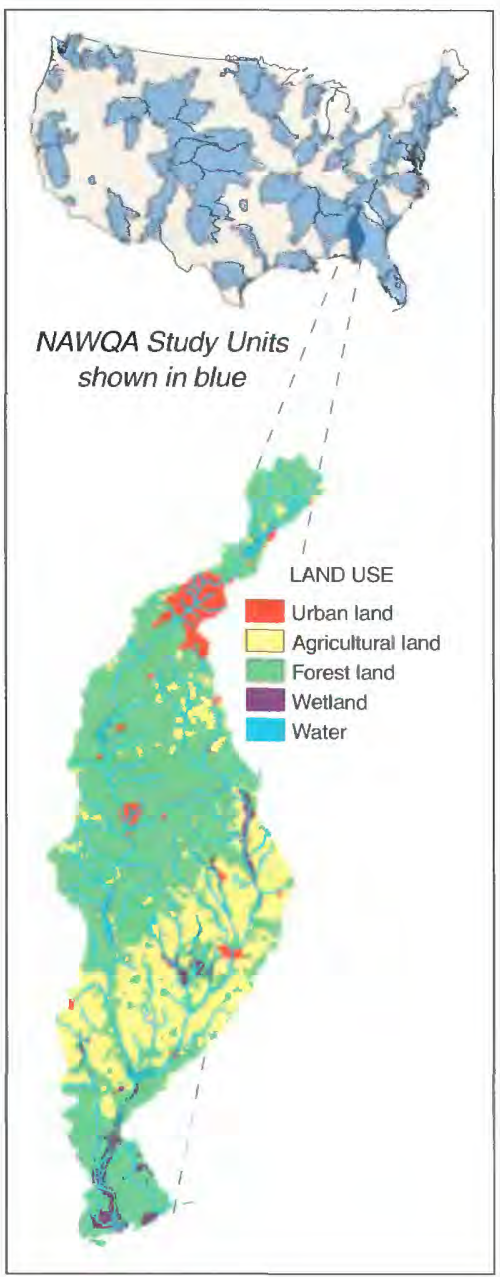

The goal of the

study is to

document water

quality and

describe the

effects of land uses

on water quality in

the Apalachicola-

Chattahoochee-

Flint River basin
Physical, chemical, and biological data were collected to assess surface- and groundwater quality in the Apalachicola-Chattahoochee-Flint (ACF) River basin from August 1992 through September 1995, as part of the U.S. Geological Survey (USGS) National Water-Quality Assessment (NAWQA) program. Surface-water-quality data were collected at 132 stream sites and at 15 locations within 6 reservoirs. Ground-waterquality data were collected at 161 sites. These data and associated information are accessible on the World Wide Web (WWW) from the ACF NAWQA home page (http://wwwga.usgs.gov/nawqa/). Data are presented in tables that are grouped by land use, site type, and project component. The user can view data tables on the computer screen or download data tables as relational data-base (tab-delimited ASCII) files. In addition to providing access to data, the ACF NAWQA home page provides information pertaining to the ACF River basin that includes (1) a detailed basin description, (2) various ACF River basin descriptive maps, (3) access to ACF NAWQA publications, and (4) links to other relevant web pages.

\section{INTRODUCTION}

The USGS NAWQA program is designed to describe the status and trends in the quality of the Nation's ground- and surface-water resources, and to provide a sound understanding of the natural and human factors that affect the quality of these resources (Leahy and others, 1990). In 1991, the Apalachicola-Chattahoochee-Flint River basin was selected for study in the NAWQA program (fig. 1).

Data collection began in August 1992 and continued through September 1995. During this period, water-quality data were collected at 308 sites, including 132 stream sites; at 15 locations within 6 reservoirs; and at 161 ground-water sites, including wells, springs, drains, and seeps. Surface-water samples were collected at frequencies varying from hourly to annually, depending upon the intended purpose, and samples were analyzed for nutrients, carbon, pesticides, and major ions; field measurements included specific conductance, temperature, $\mathrm{pH}$, dissolved oxygen, and alkalinity. As many as 80 samples were collected at several surfacewater sites during the study period. Groundwater samples also were collected at varying frequencies, depending upon the purpose, and were analyzed for the same constituents. Ground-water samples also were analyzed

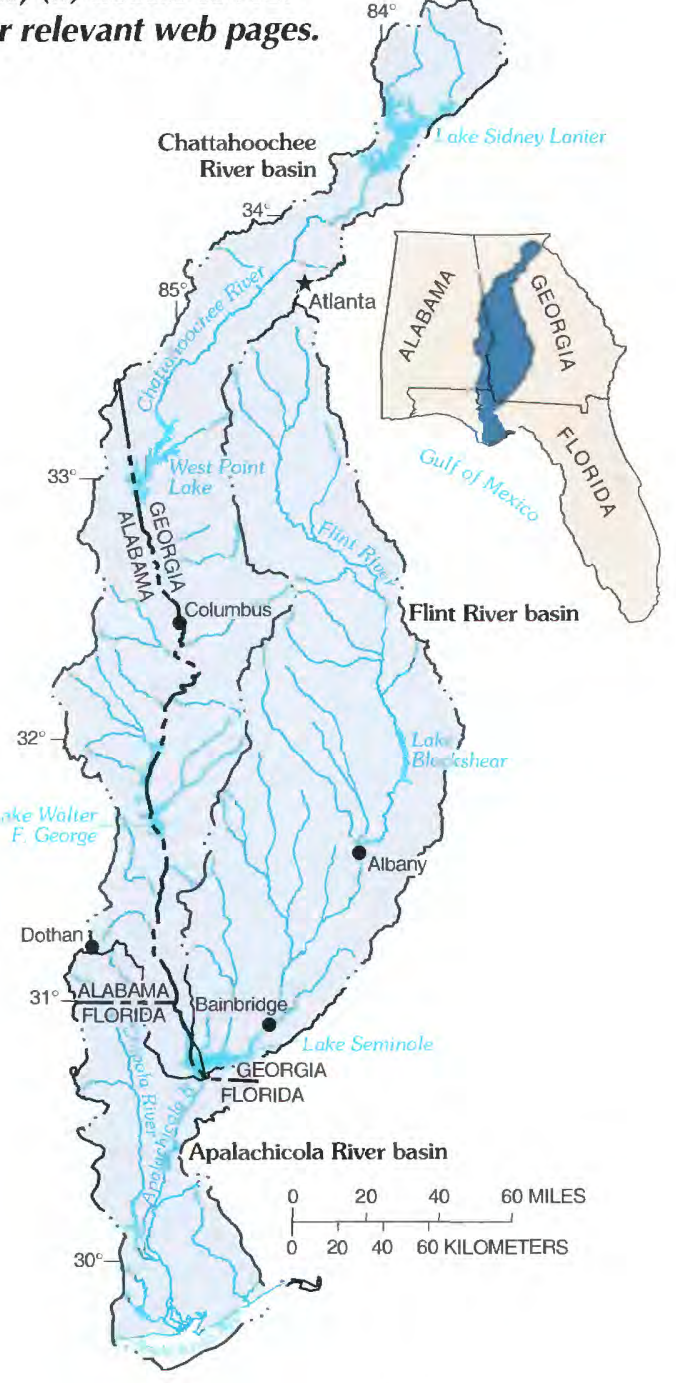

Figure 1. Location of the ApalachicolaChattahoochee-Flint (ACF) River basin 
for volatile organic compounds, trace metals, radionuclides, and stable isotopes. At selected surface-water sites, bed sediments and tissue of the Asiatic Clam (corbicula fluminea) were analyzed for metals and organic compounds; and ecological surveys of fish, algae, and macroinvertebrates were conducted. Although no samples were analyzed for each constituent, the complete list of analytes includes 470 constituents.

\section{DESCRIPTION OF ACF NAWOA HOME PAGE}

The ACF NAWQA home page can be accessed through the WWW at the following address:

\section{http://wwwga.usgs.gov/nawqa/}

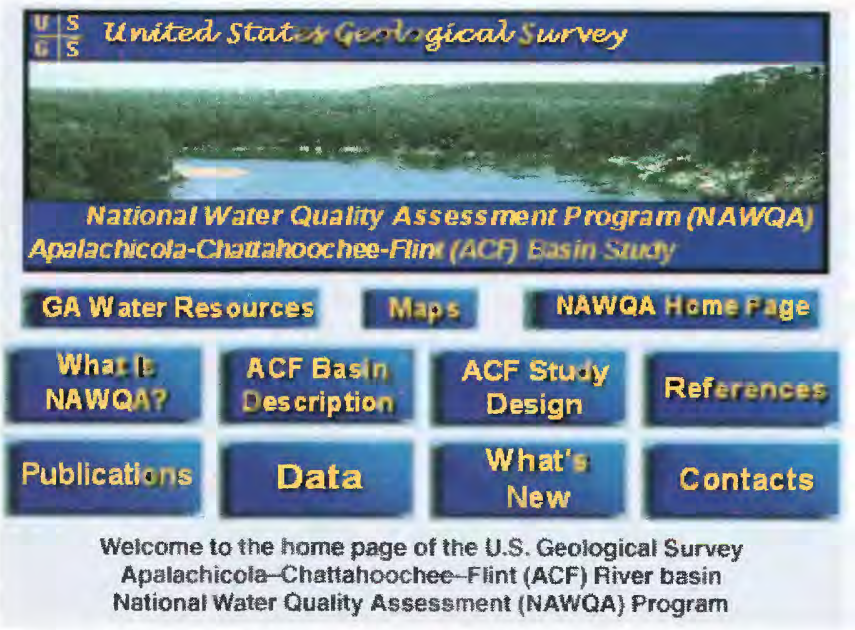

Figure 2. U.S. Geological Survey ACF NAWQA home page.

The home page (fig. 2) allows the user to select from several options that are briefly described below:

What is NAWQA? - This option provides a one-page narrative that describes the goals of the USGS NAWQA program.

ACF Basin Description - This option provides a detailed description of the environmental setting of the ACF River basin including location, physiography, soils, climate, and surfaceand ground-water hydrology. The user also can view various maps formatted as GIF images including location, land use, generalized outcrop areas of aquifers, land-resource areas, and physiographic provinces.

ACF Study Design-This option describes NAWQA terminology and details of the sampling design for each study component. This section is divided into three parts that describe surface-water, ground-water, and special study components. The text is subdivided by site type to allow the user to scan topics of specific interest.

Data - This option provides access to data tables (described in detail below).

What's New-This option includes a list of new reports and updates on new ACF NAWQA related projects.

Contacts - This option gives the user direct links to other WWW sites of interest. One example is the U.S. Census
Bureau's Tiger Mapping Service page, which allows users to construct customized maps. The Tiger Mapping Service was used to produce several site-location maps used in the NAWQA home pages.

References - This option provides a bibliography of information sources that are referenced by the ACF NAWQA web pages, and other information sources that provide additional background on the ACF River basin. From here, the user can link directly to other NAWQA and USGS publications lists.

Publications-This option allows users to read short interpretive reports and abstracts of longer reports published during the ACF River basin NAWQA study. A form with check boxes (fig. 3) allows a user to request paper copies of available reports by selecting the reports, providing a return address, and sending the request directly to the USGS via electronic mail. ACF NAWQA reports are free upon request as long as supplies are available. When supplies are exhausted, NAWQA reports, along with many other USGS reports, may be purchased from the U.S. Geological Survey, Branch of Information Services, Denver Federal Center, Box 25286, Denver, CO 80225-0286.

GA Water Resources - This option provides access to the USGS public home page for Georgia, "Water-Resources Information."

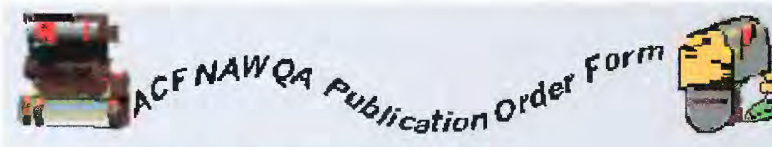

(1) Enter your name and mailing address:

Joe Smith
1500 Cranberry Lane
Anywhere, GA

(2) Enter your e-mail address $\longdiv { \text { jsmith@anon.gov } }$

(3) Choose a publication(s):

Water Resources-liwestigations Report

- $\sqrt{x}$ Influences of Enviromental settings on aquatic ecosystems in the ACF

- $\Gamma$ Nutrient sources and analysis of nutrient water-quality data, ACF

Open-File Reports

- $\Gamma_{\mathbf{X}}$ Use and occurrence of pesticides in the ACF

- $\Gamma$ National Water-Quality Assessment Program-The ACF

Conference Proceedings

Proceedings public ations include $A C F$ NAWQA reports oniy

- $\Gamma$ Reprints from proceedings of the 1993 Georgia Water Resources Conference

- $\sqrt{\mathbf{x}}$ Reprints from proceedings of the 1995 Georgia Water Resources Conference

(4) CommentsiAdditional Information:

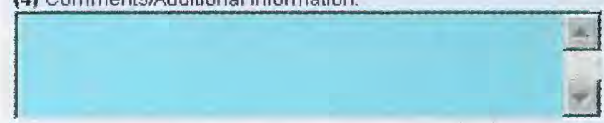

Finished? You can. Send this form or Resel Form |

Figure 3. ACF NAWQA publication order form.

Maps - This option provides a complete list of maps available for this NAWQA ACF web site.

NAWQA Home Page - This option provides access to information about the National NAWQA program and allows links to other NAWQA web sites throughout the United States.

United States Geological Survey-This option, located in the banner at the top of the ACF NAWQA home page (fig. 2), 
provides access to the USGS public home page. This home page provides information on the Nation's water resources, biological resources, geology (including earthquakes and volcanoes), mapping activities, and other data and publications.

\section{DESCRIPTION OF DATA OPTIONS}

The Data menu (fig. 4) of the ACF NAWQA home page is divided into two sections-informational text and data tables.

\begin{tabular}{|c|c|}
\hline TEXT OPTIONS & DATA OPTIONS \\
\hline Abstract & Surface-Water Data \\
\hline Introduction & Ground-Water Data \\
\hline Study Design & Special-Studies Data \\
\hline Glos sary of Terms & Stream flow Data \\
\hline $\begin{array}{l}\text { Descriptions of } \\
\text { Data Sets }\end{array}$ & $\begin{array}{l}\text { Ancillary Data } \\
\text { Quality As surance Data }\end{array}$ \\
\hline
\end{tabular}

Figure 4. ACF NAWQA text and data menu options.

The text section includes an Abstract, Introduction, an abbreviated version of the Study Design, Glossary of Terms, and Description of the Data Sets by study component. Detailed lists of surface- and ground-water sites can be obtained from the abbreviated Study Design. These lists include a numbered site identifier, site name, map identifier, detailed basin land use, latitude, longitude, and site type for each data-collection site. The Descriptions of Data Sets page describes the types of data collected for each study component. From here, the user can access groups of water-quality constituents (nutrients, for example), constituent lists (nitrate or phosphate, for example), and method detection levels for each constituent.

Data tables are available for surface water, ground water, special studies, streamflow, ancillary, and quality assurance for the ACF NAWQA River basin. The data are further subdivided into groups consisting of related water-quality constituents. The data tables can be viewed on the screen or downloaded to a user's computer as relational data-base (tab-delimited ASCII) files. To limit the need for excessive scrolling, the tables are as compact as possible. Compounds that were analyzed for, but not detected at any site within a group, are not listed in the tables. A Glossary of Terms link is provided with each table, and includes terms unique to the NAWQA program: many general terms associated with water quality and streamflow; and definitions for the measurement units used within the tables.

The surface-water monitoring networks include six or more sampling sites that are grouped by land use and site type. The study design includes three land-use types - urban/suburban, silviculture, and agriculture. Agricultural land use is subdivided as poultry production in the northern part of the ACF River basin, row-crop production overlying clastic geology, and rowcrop production overlying karst geology in the southern part of the ACF River basin. Site types are classified as streams draining small watersheds (ranging in area from about 3 to 100 square miles) predominated by one land use, or as mainstem river or tributaries that have larger drainage areas and mixed land use. The user has options to view location maps (for example, see figure 5) or select a specific land use (poultry production, for example), and view a table that lists sites representative of that land use with the numbers of samples, by constituent group (nutrients or pesticides; for example, see figure 6) at each site.

The ground-water monitoring network is composed of four project components that are described in detail in the ACF Study Design - study-unit survey, urban land-use study, agricultural land-use study, and a flow-system study. A combination of wells, springs, and drains comprises the network for each study component. Data from each component are listed in separate tables that can be viewed or downloaded. The user is presented with a matrix table of clickable options that allow access to a constituent group of interest (pesticides, for example) from the ground-water component (urban land use, for example), and then the site type (wells, for example) of interest (pesticide data from urban land-use wells; for example, see figure 7). A map and list of sites associated with each groundwater study component also are available. The ground-water data viewing and downloading pages are designed to offer many options on one screen, limiting the levels a user needs to navigate to reach the data of interest.

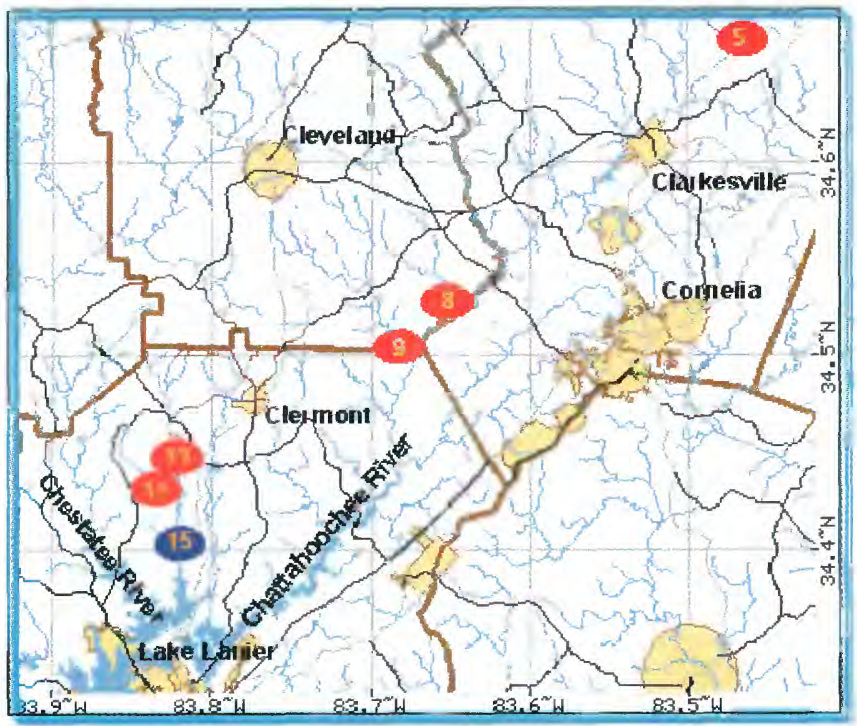

Figure 5. Poultry land-use sites in the ACF NAWQA.

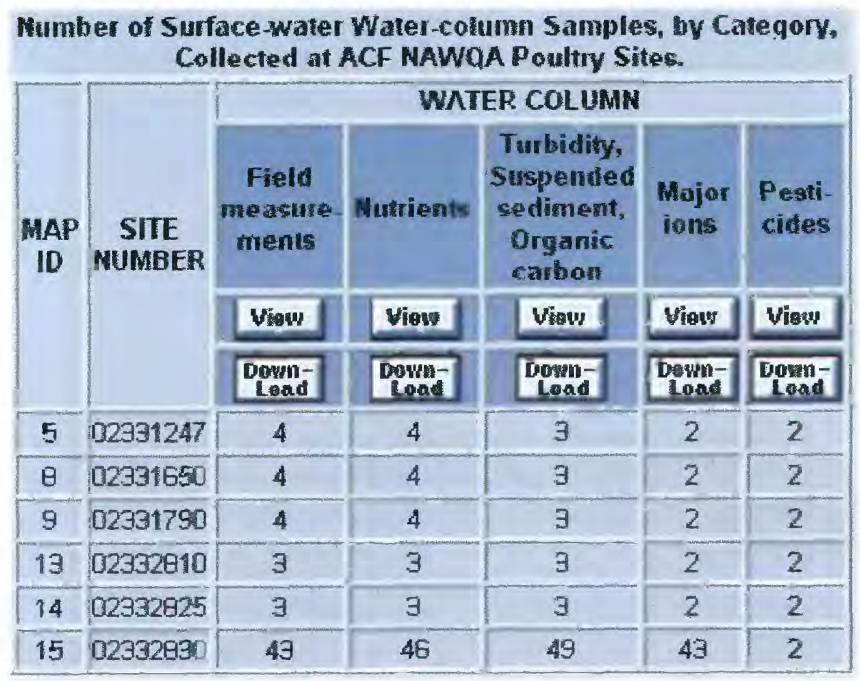

Figure 6. Surface-water water-column samples, by category, collected at ACF NAWQA poultry sites. 


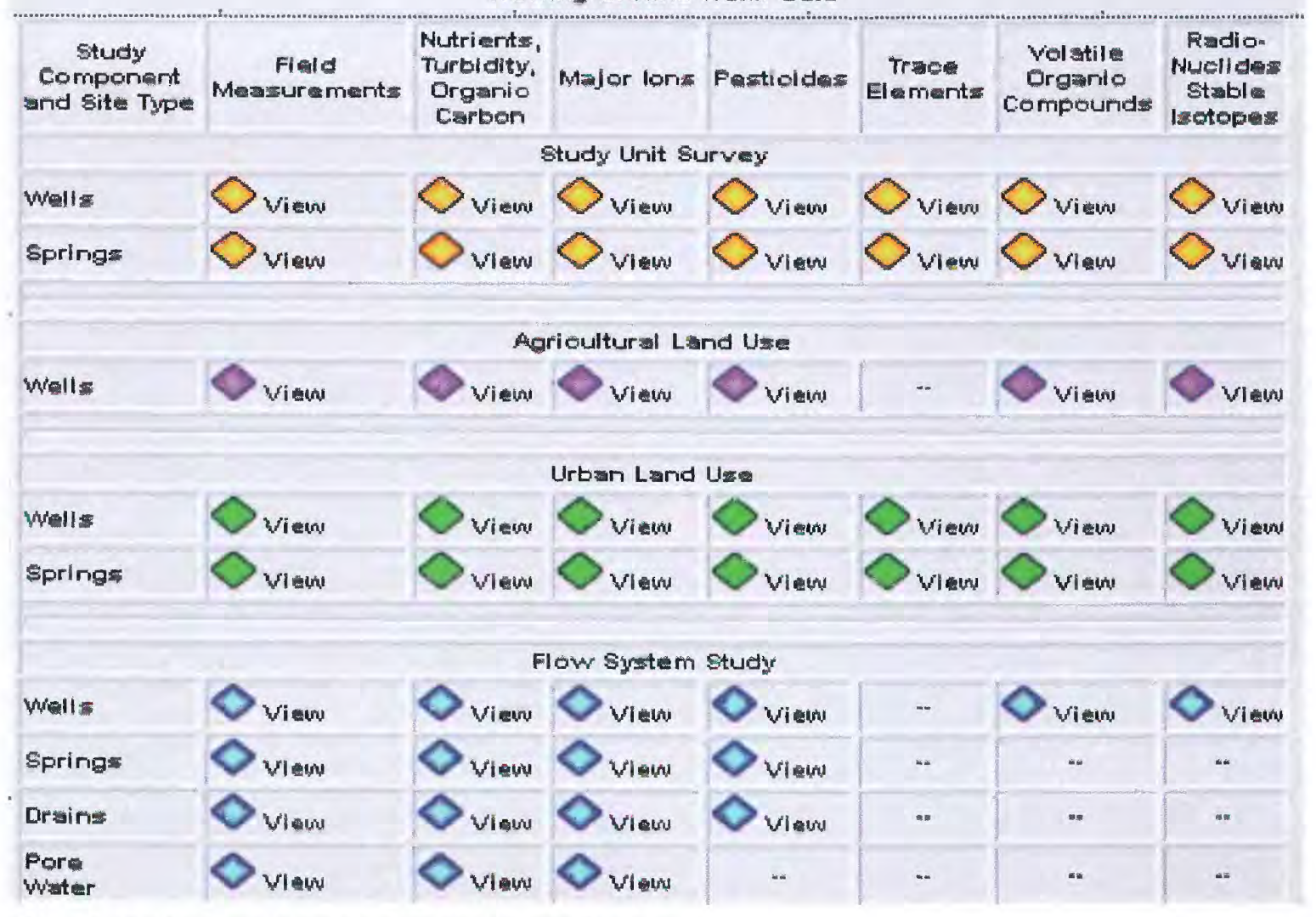

Figure 7. Viewing ground-water data menu, ACF NAWQA page.

The study design for the ACF River basin also includes four special studies: (1) surface-water synoptic surveys conducted to determine spatial distribution of nutrients and pesticides, to better define the effects of poultry, urban, and suburban land uses;

(2) sediment cores collected from five reservoirs in the basin to better define longterm trends; (3) water-quality data collected during the flooding that followed record rainfall produced by Tropical Storm Alberto in July 1994; and (4) a study of the recovery of the native fish community at a small watershed following record flooding resulting from Tropical Storm Alberto. Data from these studies are available for viewing or downloading. Site-location maps also are available for each special study.

Streamflow Data, Ancillary Data, and Quality-Assurance Data comprise the last three data options. Streamflow Data provides access to daily mean discharge values for nine sites that comprise the core of the surface-water monitoring network. Ancillary Data provides access to site maps, site lists, constituent lists, a glossary of terms, and other information associated with this web site. Quality-Assurance

Data provides access to quality assurance and quality-control data, such as blanks, replicates (for example, see figure 8), and spikes, that are presented in tables and graphs for most constituents analyzed in water during the ACF River basin NAWQA study.

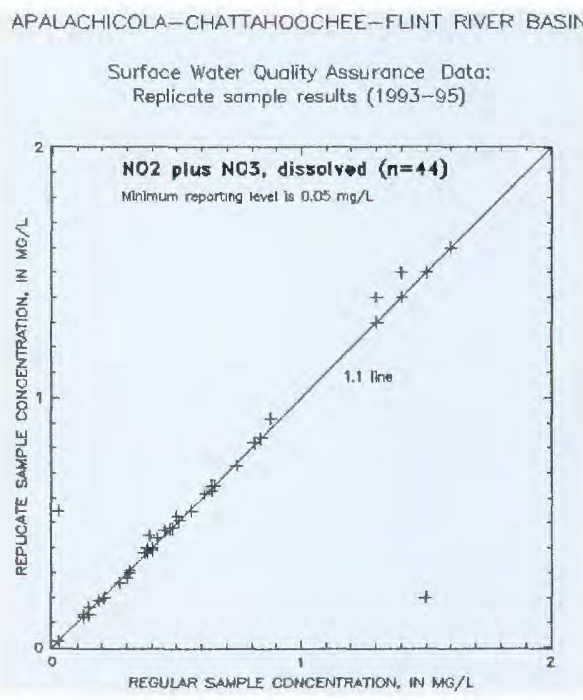

Figure 8. ACF surface-water quality assurance data, replicate sample results, 1993-95.

\section{REFERENCE}

Leahy, P.P., Rosenshein, J.S., and Knopman, D.S., 1990, Implementation plan for the National WaterQuality Assessment Program: U.S. Geological Survey Open-File Report 90-174, 10 p.

-By Jerry W. Garrett, Howard A. Perlman, and Judith Scholz

Reports and data related to the ACF

NAWQA program can be obtained from:

ACF NAWQA Program Manager

U.S. Geological Survey

Peachtree Business Center

3039 Amwiler Road

Suite 130

Atlanta, GA 30360-2824

National Water-Quality Assessment Program 